\title{
Mosaicism with a normal cell line and an autosomal structural rearrangement
}

\author{
R J M Gardner, H E Dockery, P H Fitzgerald, R G Parfitt, D R Romain, N Scobie, \\ R L Shaw, P Tumewu, A J Watt
}

\begin{abstract}
Over three decades, 12 cases of mosaicism for an autosomal rearrangement were recognised in the major cytogenetics laboratories in New Zealand, eight of which were studied between 1990 and 1992. One case inferentially involved the gonad, eight the soma, and three both gonad and soma. This mosaicism could have arisen as a postzygotic event either in a conceptus that was initially normal, with the generation of an abnormal cell line, or in a conceptus having a supernumerary chromosome which was lost at a subsequent mitosis, thereby restoring a normal cell line. Three of the 12 cases involved a presumed direct duplication, an otherwise very uncommon rearrangement. This may indicate a propensity for direct duplications to arise at mitosis rather than at meiosis; unequal sister chromatid exchange is a plausible mechanism. Mosaicism has clinical relevance for genetic counselling, as an intragonadal cell line carrying a rearrangement could generate multiple unbalanced gametes. Mosaicism for an autosomal rearrangement may be very much more common than is, or ever could be, recognised.
\end{abstract}

( $($ Med Genet 1994;31:108-114)

Mosaicism for a normal cell line and an unbalanced autosomal structural rearrangement is rarely seen. If the abnormal cell line is widespread and contributes to a substantial fraction of the soma, it is likely to cause dysmorphism and malformation and, if the brain is included, intellectual deficit. If it involves only a small fraction of the soma, or parts of the soma whose integrity is not compromised by the aneuploidy, it would never be recognised, unless fortuitously. If it contributes to gonadal tissue, with little or no somatic involvement, it could only be recognised as such in the next generation, following the detection of more than one pregnancy outcome (abnormal baby, products of conception) with the same chromosome abnormality.

Mosaicism for a normal cell line and an apparently balanced autosomal structural rearrangement would not, other things being equal, and whatever its extent within the soma, be expected to cause phenotypic abnormality. However, such mosaicism, if it includes gonadal tissue, could lead to the production of chromosomally unbalanced gametes and consequent reproductive abnormality.

These types of defect presumably arise in two main ways. In the first, the conceptus is karyotypically normal, but an event during an early mitotic cycle generates a cell line (or lines) with an abnormal chromosome. The karyotype, at outset $46, \mathrm{~N}^{*}$, comes to be $46, \mathrm{~N} /$ 46 ,rea or $46, N / 47,+$ rea. In the second, the karyotype at conception is abnormal, with a supernumerary chromosome or "extra structurally abnormal chromosome" (ESAC), and at an early mitosis a cell loses the ESAC and its lineage thereafter has a normal chromosome constitution. The karyotype, at outset $47,+$ ESAC, comes to be $46, \mathrm{~N} / 47,+\mathrm{ESAC}$. Formally, it is not usually possible to distinguish between which of these two (or possibly other) mechanisms could have operated. According to the stage of development and embryonic part, and perhaps relative proliferative advantage, the abnormal cell line comprises a greater or lesser fraction of the embryo.

We describe 12 examples of mosaicism for a structural rearrangement, one recognised inferentially in gonad, eight in soma, and three in both gonad and soma. Three of the rearrangements are direct duplications, and we focus our discussion upon this specific category.

\section{Case reports \\ CASE 1}

Two adult brothers came to cytogenetic study in 1976 because of severe mental retardation and minor dysmorphic signs. Each had an identical rea(8q). The chromosomal morphology was consistent with a direct duplication: $46, X Y$, dir $\operatorname{dup}(8)(q 21 \rightarrow q 22)$ (figure). The parents had normal karyotypes, both on peripheral lymphocyte (50 cells) and skin fibroblast $(20$ cells) analysis. They were of normal intelligence and physical phenotype. Two other sibs, phenotypically normal, also had normal karyotypes (lymphocyte study only). We presume one parent carried the rea $(8)$ in gonadal tissue. Formally, we cannot exclude the abnormal chromosomes as $\operatorname{der}(8)$ resulting from a parental $t(8 ;$ ?), but the physical and intellectual phenotype is similar to that of pure trisomy for the segment $8 \mathrm{q} 21.2 \rightarrow \mathrm{q} 22,{ }^{1}$ and thus a dir dup is an attractive candidate mechanism. No FISH studies have been done.

* For simplicity's sake, we use $46, \mathrm{~N}$ ( $\mathrm{N}$ to denote normal) to indicate $46, \mathrm{XY}$ or $46, \mathrm{XX}$. ' $\mathrm{A}$ ' indicates any autosome. 


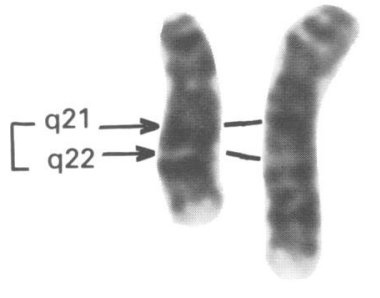

8 dir dup(8)

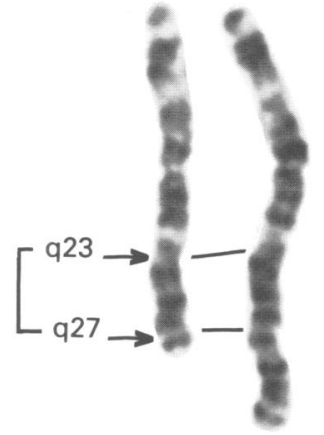

3 dir dup(3)

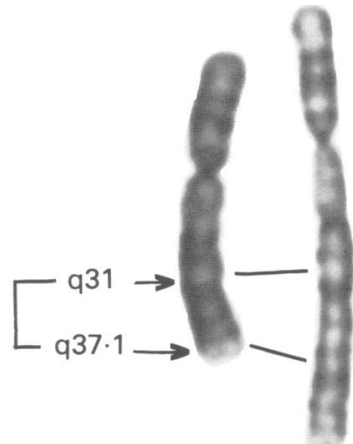

$2 \operatorname{dir} \operatorname{dup}(2)$

Partial karyotypes of the duplications 8,3 , and 2 from cases 1,5 , and 6 respectively. Case 1 is dir dup (8) (q21 $\rightarrow q 22)$, case 5 is dir $\operatorname{dup}(3)(q 23 \rightarrow q 27)$, and case 6 is dir dup $(2)(q 31 \rightarrow q 37.1)$. The duplicated segments are indicated on the normal homologues between arrows.

CASE 2

An infant with minor dysmorphic signs had the karyotype $46, \mathrm{XX} / 47, \mathrm{XX},+$ mar. The abnormal chromosome could not be identified, although its symmetry suggested an isochromosome. On peripheral blood studies, the ratio of normal to aneuploid cells was 24:6 at 12 days; by 9 months the ratio was $70: 2$, and by 2 years the abnormal chromosome had disappeared. This case has been described in detail elsewhere. ${ }^{2}$

CASE 3

A newborn girl, small for dates, was studied because of a prenatal diagnosis of mosaic trisomy 20 , amniocentesis having been done on the basis of the mother's age of 44 years. Peripheral lymphocytes had the karyotype $46, \mathrm{XX}$, but urine epithelial cells were $46, \mathrm{XX}, \mathrm{t}(3 ; 12 ; 17)(\mathrm{p} 21 ; \mathrm{q} 13 ; \mathrm{p} 13)$ in all 50 cells studied. No $47,+20$ cells were seen. A skin biopsy failed to culture and no repeat urine study was done. The child is therefore presumed to be mosaic $46, \mathrm{~N} / 46, \mathrm{t}(3 ; 12 ; 17)$ (p21;q13;p13), the abnormal cell line involving at least much of the kidneys; any distribution elsewhere than in blood forming tissue remains an open question. On review at the age of 14 months, length at $73.2 \mathrm{~cm}$ was about the $25 \mathrm{th}$ centile, weight at $7.4 \mathrm{~kg}$ was below the $3 \mathrm{rd}$ centile, and head circumference at $44.5 \mathrm{~cm}$ was on the 3rd centile. Neurodevelopmental progress was normal. She has been lost to follow up.

CASE 4

A 4 year old girl had delayed development in motor milestones, and very limited language. She had a subtle degree of midfacial hypoplasia and borderline microcephaly, but was otherwise of normal physical phenotype. CT scan later showed partial agenesis of the corpus callosum. On lymphocyte analysis, she had the karyotype $46, \mathrm{XX} / 46, \mathrm{XX}, \mathrm{r}(?)$, the ring being a very small chromosome not further defined. No FISH studies have been done. The ratio of normal to aneuploid cells was 14:86.

CASE 5

An infant girl had a clinical picture suggestive of Cornelia de Lange syndrome, and also showed hypomelanosis of Ito. On lymphocyte analysis, she had the karyotype $46, \mathrm{XX}$ / $46, \mathrm{XX}$, dir $\operatorname{dup}(3)(\mathrm{q} 23 \rightarrow \mathrm{q} 27)$ (figure), the ratio of normal to aneuploid cells being 36:64. A similar ratio was noted in amniotic fluid cells, amniocentesis having been done on the basis of advanced maternal age.

\section{CASE 6}

A 13 year old boy with mild mental retardation but no dysmorphic features had the karyotype $46, \mathrm{XY} / 46, \mathrm{XY}$, dir $\operatorname{dup}(2)(\mathrm{q} 31 \rightarrow \mathrm{q} 37.1)$ (figure). The ratio of normal to aneuploid cells was $70: 30$ in lymphocytes and 60:40 on skin fibroblast study.

CASE 7

The mother of a child with an 18q- karyotype had the chromosome constitution $46, \mathrm{XX}$ $46, \mathrm{XX}, \mathrm{rcp}(5 ; 18)(\mathrm{p} 15 ; \mathrm{q} 21) ; 999 / 1000$ lymphocytes and $200 / 200$ skin fibroblasts were $46, \mathrm{XX}$ and only one lymphocyte had the translocation. We take her to be a somatic-gonadal mosaic. This case is to be the subject of a detailed report elsewhere.

CASE 8

A 14 year old boy with a clinical picture suggestive of Smith-Magenis syndrome had the karyotype, on lymphocyte study, of $46, \mathrm{XY} / 46, \mathrm{XY}, \operatorname{del}(17)(\mathrm{p} 11.2 \mathrm{p} 11.2)$, the ratio of normal to abnormal cells being $14: 86$.

CASE 9

Three brothers with mental retardation were studied cytogenetically, the suspected diagnosis being fragile $\mathrm{X}$ syndrome. This was confirmed. One of the brothers showed, from one blood sample, 4/100 cells with the apparently balanced translocation $\operatorname{rcp}(4 ; 20)(\mathrm{p} 16 ; \mathrm{q} 13)$, and on a separate blood sample, $5 / 100$ cells with this translocation. One cell showed both the $\operatorname{rcp}(4 ; 20)$ and the fragile $\mathrm{X}$.

CASE 10

A child presented with growth deceleration and had the karyotype $47, \mathrm{XX},+$ inv $\operatorname{dup}(15)$; 
neurodevelopmental function was grossly intact. The phenotypically normal mother's karyotype, on peripheral blood, was $46, \mathrm{XX}$ / $47, \mathrm{XX},+\operatorname{inv} \operatorname{dup}(15)$; the ratio of normal to abnormal cells was 83:17. We have not studied her parents, and so it remains open whether her conception was $46, \mathrm{XX}$ or $47, \mathrm{XX},+$ inv $\operatorname{dup}(15)$

CASE 11

A 9 year old boy presenting with intellectual deficit, behavioural abnormalities, and epilepsy, but no dysmorphic features had, on lymphocyte analysis, the karyotype $46, \mathrm{XY}$ / $46, X Y, r(20)$. The ratio of normal to abnormal cells was 61:44.

CASE 12

A woman had amniocentesis and the fetal karyotype was $47,+\operatorname{der}(22), \mathrm{t}(11 ; 22)(\mathrm{q} 23 ; \mathrm{q} 21)$ Her husband carried the common $\operatorname{rcp}(11 ; 22)$ (q23;q21), and his mother had, on lymphocyte analysis, the karyotype $46, \mathrm{XX} / 46, \mathrm{XX}, \mathrm{rcp}(11 ; 22)$ (q23;q21). The ratio of normal to abnormal cells was 20:33. This case is to be the subject of a brief report elsewhere.

\section{Discussion}

Mosaicism for an autosomal rearrangement, with one cell line being $46, \mathrm{~N}$, is uncommonly reported. Concerning balanced rearrangements, an impression of the relative frequency is gained by reference to the series of Kleczkowska et $a l{ }^{3}$ comprising a whole cytogenetically studied population. They reviewed the experience in Leuven over 1966 to 1989 and, of 74306 cytogenetic patients, found only six in whom there was such mosaicism. Two were mosaic for a reciprocal translocation, one for an insertional translocation, and three for an inversion. The former three were: $46, \mathrm{~N} / 46, \mathrm{t}(1 ; 9)$ (p13.1;p12.2); 46,N/46,t $(9 ; 13)(\mathrm{p} 21 ; \mathrm{q} 13) ;$ and 46 , $\mathrm{N} / 46$,ins $(14 ; 13)$ (q24.1;q31.1q32.3). In Schinzel's catalogue of unbalanced aberrations, ${ }^{4}$ a very small fraction of the individual cases listed in the author index are mosaic for an autosomal rearrangement. These comprise deletions, duplications, rings, and an isodicentric, as follows: $46, \mathrm{~N} / 46, \operatorname{del}(2)(\mathrm{q} 23 \rightarrow \mathrm{q} 34)$; $46, \mathrm{~N} / 47,+\operatorname{del}(8 \mathrm{p}) ; 46, \mathrm{~N} / 47,+\operatorname{dup}(8)(\mathrm{p} 11 \rightarrow$ qter $) ; 46, \mathrm{~N} / 46,-8,+\operatorname{isodic}(8)(\mathrm{p} 21) \rightarrow \mathrm{qter})$; $46, N / 47,+\operatorname{dup}(9)($ pter $\rightarrow \mathrm{q} 33) ; 46, \mathrm{~N} / 46, \operatorname{del}(12)$ (q13) (?cultural artefact); 46, $\mathrm{N} / 46, \mathrm{del}(15)$ $(\mathrm{q} 12 \rightarrow \mathrm{q} 14) ; 46, \mathrm{~N} / 46, \operatorname{del}(18 \mathrm{p}) ; 46, \mathrm{~N} / 46, \operatorname{del}(18)$ (q21 $\rightarrow$ qter); 46,N/46,r(18); 46,N/46,r(19); $46, N / 46, r(21)$. Some of the above cases, by virtue of the birth of one or more child with the abnormal chromosome in non-mosaic state, allow inference of somatic-gonadal mosaicism.

Gonadal mosaicism is a concept with important practical relevance. Published papers on individual cases of mosaicism for a structural rearrangement and a normal cell line include the following which have possible, probable, or certain gonadal involvement. Chilcote $e t a l^{5}$ described sibs with identical deletions of chromosome 8 , the parents and two other sibs being cytogenetically normal. One parent was presumably, therefore, a gonadal mosaic. Sciorra et al $l^{6}$ detected very low level mosaicism ( $1 / 100$ blood cells, $0 / 100$ fibroblasts) for a 7;14 translocation in a father, the $\operatorname{der}(7)$ initially having been detected in unbalanced state in his abnormal son. In the 46,N/ $46, t(1 ; 9)$ case of Kleczkowska et $a l^{\beta}$ noted above, a father had $50 \%$ mosaicism for the abnormal cell line, the translocation having being identified in two daughters (in nonmosaic balanced state) at prenatal diagnosis; and similarly Farrell ${ }^{7}$ reported a woman who was $46, \mathrm{~N} / 46, \mathrm{t}(5 ; 18)(\mathrm{q} 35.1 ; \mathrm{q} 21.3)$, ascertained through her son's being non-mosaic $46, t(5 ; 18)$. Friedman et $a l^{8}$ described a mother who was $46, \operatorname{del}(17)(\mathrm{p} 11.2 \rightarrow \mathrm{cen}) / 47, \operatorname{del}(17)(\mathrm{p} 11.2 \rightarrow \mathrm{cen})$, $+\mathrm{rea}(17)(\mathrm{p} 11.2 \rightarrow \mathrm{cen})$ and a son who was $46, N / 47,+$ rea(17). Presumably the small supernumerary chromosome had, in each, been lost as a somatic event in one cell lineage. Hajianpour et al reported a couple having had one child with cri du chat syndrome, and $5 \mathrm{p}$ - shown in a subsequent pregnancy. Brandriff $e t a l^{10}$ attempted a direct demonstration of germ cell mosaicism by studying sperm chromosomes in the father of two children with $\operatorname{del}(13)(q 22 q 23)$; no mosaicism was found. Yang and Rosenberg ${ }^{11}$ identified 46,N/ $45, \operatorname{rob}(21 ; 22)$ mosaicism in the matriarch of a translocation Down's syndrome kindred. (While a postzygotic generation of this Robertsonian translocation seems very probable, it is interesting to note the unique case of Pflueger $e t$ $a l^{12}$ in which, apparently, a mitotic event reversed a rob(13;22) by a "back mutational" fission.) Kruger $e t a l^{13}$ reported an infant and a fetus with an isochromosome of $18 \mathrm{q}$, the parents' karyotypes on peripheral blood being normal. Croci and Franchi ${ }^{14}$ described 46,N/ $46,-21,+\mathrm{t}(21 \mathrm{q} 21 \mathrm{q})$ mosaicism in the mother of a child with (21q21q) Down's syndrome, and discussed whether this particular category of mosaicism may be not infrequent among parents of such children. Bartsch et $a l^{15}$ reported a similar case studied by in situ hybridisation techniques. Some subjects have presented through multiple miscarriage, and it remains an open question whether the cytogenetic abnormality was causally related to the clinical problem. Examples include the following. The proband in D'Alessandro et $a l^{16}$ was $46, \mathrm{~N} / 46, \operatorname{del}(6)(\mathrm{p} 23-\mathrm{pter})$. Sciorra et $a l^{17}$ ascertained a woman whose blood karyotype, on repeated samplings, was $46, N$ / $46, \mathrm{t}(4 ; 5)(\mathrm{q} 21 ; \mathrm{q} 34)$, although who on skin fibroblast study was $46, N$. The $46, N / 46, t(9 ; 13)$ case of Kleczkowska et $a l^{\beta}$ noted above was the husband of a woman who had two miscarriages. Farrell ${ }^{7}$ describes a couple with infertility, the male partner being $46, \mathrm{~N} / 46, \mathrm{t}(3 ; 6)(\mathrm{q} 13 \cdot 2 ; \mathrm{q} 25 \cdot 3)$ on separate blood samples.

Many cases are ascertained because of an abnormal phenotype in the mosaic subject, and some representative examples follow. One of the earliest reports was that of Pagon et $a l^{18}$ who described two cases normal on lymphocyte study and with the abnormal chromosome (in each an ESAC not precisely identifiable) seen only on skin fibroblast analysis. Nielsen $e t$ 
Summary of all known New Zealand cases of mosaicism for a structural rearrangement. The region of somatic distribution of the mosaicism, noted in parentheses, is a minimum inference

\begin{tabular}{|c|c|c|c|}
\hline Case & Region & $N$ :abn ratio & Karyotype \\
\hline $\begin{array}{l}1 \\
2 \\
3 \\
4 \\
5 \\
6 \\
7 \\
8 \\
9 \\
10 \\
11 \\
12\end{array}$ & $\begin{array}{l}\text { Gonad* } \\
\text { Soma (blood) } \\
\text { Soma (blood/kidney) } \\
\text { Soma (blood) } \\
\text { Soma (amniocyte/blood) } \\
\text { Soma (blood/skin) } \\
\text { Soma/gonad* } \\
\text { Soma (blood) } \\
\text { Soma (blood) } \\
\text { Soma (blood)/gonad* } \\
\text { Soma (blood) } \\
\text { Soma (blood)/gonad* }\end{array}$ & $\begin{array}{l}? \\
24: 6 \rightarrow 100: 0 \\
50: 0 / 0: 50 \\
14: 86 \\
36: 64 \\
70: 30 / 60: 40 \\
200: 0+, 999: 1 \ddagger / ? \\
14: 86 \\
191: 9 \\
83: 17 ? \\
61: 44 \\
20: 33 ?\end{array}$ & 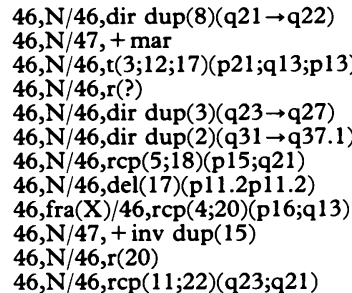 \\
\hline
\end{tabular}

* Inferentially.

The karyotype in cases $1,2,4,5,6,8,10$, and 11 is unbalanced; in cases 7,9 , and 12 it is balanced.

$a l^{19}$ reported a physically and mentally abnormal woman with $46, \mathrm{~N} / 46$,ins(14)(pter;q21 q31)del(14)(q31-qter). Saura et $a l^{20}$ described a dysmorphic infant whose 6 month psychomotor development was normal, who had the karyotype $46, \mathrm{~N} / 46, \mathrm{t}(8 ; 12)(\mathrm{p} 23 \cdot 2 ; \mathrm{q} 13 \cdot 3)$ on two separate blood samplings and at skin fibroblast culture. Mosaicism for a deletion chromosome includes $46, \mathrm{~N} / 46, \operatorname{del}(18 \mathrm{q}) .^{21}{ }^{22}$ In the specific case of the isochromosome, Robinow et $a l^{23}$ described mosaicism for $\mathrm{i}(8 \mathrm{p})$, and Stanley et $a l^{4}$ reported one case of mosaic $i(5 p)$. The $i(12 p)$ mosaic state is sufficiently frequent that its phenotype is accorded eponymic status ${ }^{25}$; Priest et $a l^{26}$ discussed factors influencing the retention of the abnormal chromosome in Pallister-Killian syndrome. Reference to isochromosomes of 18 and 21 is made in the preceding paragraph. Ring chromosome mosaicism, whether $45,-\mathrm{A} / 46, \mathrm{r}(\mathrm{A})$ or $46, N / 46, r(A)$, is occasionally reported..$^{27}$ "Mosaicism" for a structural rearrangement can, in fact, be a tetragametic chimera, such as the $46, \mathrm{~N} / 46,-14,+\operatorname{der}(14)$ of Nyberg et al. ${ }^{28}$ We review the category of mosaicism for a direct duplication chromosome below.

Aughton et $a l^{29}$ reviewed three cases in which an abnormal phenotype was associated with mosaicism for an apparently balanced reciprocal translocation, the case of Saura et $a l^{20}$ above also being an example of this. They discuss that, as in the case of de novo nonmosaic balanced rearrangements, ${ }^{30}$ the possibility of a causal relation of the karyotype to the phenotype is open to argument; such associations may be coincidental.

The above, a considerable although by no means complete review, does not comprise many cases. It remains distinctly uncommon that this type of mosaicism is ever recognised. However, it is interesting that at one meeting, the International Congress of Human Genetics in Washington in 1991, quite a few single cases of $46, N / 46$,rea mosaicism, for rearrangements other than isochromosomes or rings, were presented as posters and were reported as abstracts in the proceedings of that meeting. ${ }^{91231-36}$ The cases we present (excluding case 3 with renal mosaicism) comprise eight cases with an unbalanced and three with a balanced rearrangement (table). They were identified in six New Zealand cytogenetics laboratories over the period 1976 to 1992, which crudely equates to about one case/four years/million population. Cytogenetics laboratories were established in New Zealand in the early 1960s; cases 1 and 2 were studied in the latter 1970s, cases 3 and 4 in 1986, and the remaining eight were all diagnosed in the 1990 s (thus, about one case/year/million for 1990 to 1992). This skew does suggest that cases of mosaicism from the earlier years may have escaped notice, or remained unreported or unrecorded; standards of banding, and criteria of numbers of cells counted, would have varied over that period and between laboratories. Minor degrees of mosaicism would often miss detection: if 20 cells are routinely studied, $10 \%$ mosaicism would be missed $12 \cdot 2 \%$ of the time; and if 30 cells, $10 \%$ mosaicism would be missed $4 \cdot 2 \%$ of the time (from $x=(1-m)^{n}$, where $x=$ fraction of cases missed, $m=$ true level of mosaicism, $n=$ number of cells counted). It is most remarkable that the single abnormal cell discovered in case 7 above was only the second of the thousand lymphocytes eventually analysed. The recognition that hypomelanosis of Ito may be a marker for chromosomal mosaicism has increased awareness of this biological state. Ritter et $a^{l^{7}}$ reviewed 99 cases of hypomelanosis of Ito; of 26 studied cytogenetically, 18 had mosaicism of various sorts, including three which were mosaic for a normal cell line and a structural rearrangement, as also were three of 13 cases described by Sybert et al..$^{38}$

At what point was the abnormal chromosome generated in each of our series: during meiosis or after conception? For the deletion ${ }^{17}$ (case 8) and the $t(11 ; 22)$ (case 12), the most parsimonious explanation, that of a single postzygotic event in an initially normal conceptus, seems the most likely. For the parent in case 1 , and cases 7 and 9 , in which only a small fraction, apparently, of the person's cells carried the abnormality, it is reasonable to imagine that the abnormal cell lines arose well into embryonic development and thus as somatic events. By contrast, cases 4 to 6 had their abnormal cell lines in a substantial (in cases 4 and 5 the major) fraction of cells, and the idea of an initial $47,+$ rea constitution, from an abnormal gamete, is less readily put to one side. However, cases 5 and 6 both had a direct duplication as the chromosomal abnormality; and, as we discuss below, a plausible setting for the generation of this particular rearrangement is during a postzygotic cell cycle. The marker (case 2) and the inv dup (15) (case 10), on the other hand, could have been $47,+$ rea at the outset, and possibly also the ring chromosomes (cases 4 and 11). Progressive loss over time of the abnormal chromosome may have led to the dominance of the normal cell line, as was, indeed, actually documented in case 2 . Thus, we propose that the majority $(8 / 12)$ of our cases are most likely to have had a postconception origin of the abnormal cell lineage.

It is notable that three of our 12 cases concern a direct tandem duplication. Direct duplications are a distinctly uncommon type of chromosomal rearrangement. In Borgaonkar's catalogue (table VI), ${ }^{39}$ direct duplications com- 
prise only 18 of the 4871 entries of different aberrations for various chromosomes. The review of Van Dyke ${ }^{40}$ documents 35 non-familial autosomal direct duplications, although he notes also that "many more cases exist but have never been published, partly because of uncertainty regarding exactly what is duplicated". Thus, the predominance of direct duplications in our admittedly very small series of mosaic patients is to be noted. Might it be that direct duplications are more likely to occur during a mitotic cycle than are other types of rearrangements? This proposition has some plausibility in that one mechanism which is proposed to produce a direct duplication, that of unequal sister chromatid exchange, ${ }^{40}$ does not require the synapsis of homologues and thus could, in principle, occur readily elsewhere than during meiosis. One case in the series of Van Dyke ${ }^{40}(1 / 35)$ is a mosaic direct duplication with a normal cell line, and he acknowledges the probable postzygotic origin of the duplication in this subject. Other mosaic duplications on record include the following. Serotkin et $a l^{41}$ reported an infant with an Ellis-van Creveld-like phenotype and a dir $\operatorname{dup}(17)(\mathrm{q} 21.1 \rightarrow \mathrm{q} 25)$ in $50 \%$ of lymphocytes, $100 \%$ of foreskin cells, and $67 \%$ of cells from a supernumerary toe; and Dixon et $a l^{42}$ described mosaicism for a dir $\operatorname{dup}(12)$ $(\mathrm{q} 13.1 \rightarrow \mathrm{q} 24.2)$, on two separate blood samplings, in an abnormal infant. The two cases of Harrod $e t ~ a l^{43}$ involved mosaicism for a duplication, possibly direct, of the distal segment of 12q. Jewell et $a l^{44}$ reported two separate cases of the prenatal diagnosis of $46, \mathrm{~N} / 46$,dir $\operatorname{dup}(12)(\mathrm{p} 13.1 \rightarrow \mathrm{p} 13.3)$. In one of these, the duplication chromosome was present in $60 \%$ of blood and $87 \%$ of amnion cells, but in only $2 \%$ of chorionic villi and $0 \%$ of chorionic membrane: these proportions suggest the error happened in a cell at the embryonic pole of the blastocyst in an originally normal conceptus. Pescia et $a l^{45}$ described the unique case of child mosaic for a direct duplication and a matching deletion (of $4 \mathrm{q} 13 \rightarrow 22$ ), with no normal cell line, and proposed that unequal sister chromatid exchange happened as early as during the very first mitosis of the zygote. The predominance of the duplication cell line $(70 \%)$ they ascribe to its differential survival over the deletion cell line. In the remarkable case of Masada et $a l,{ }^{46}$ gonadal mosaicism was deduced in a father whose three childen were a phenotypically normal daughter, a son with deletion of $14 \mathrm{q} 32.11 \rightarrow$ qter, and a daughter with a duplication for exactly the same segment. These authors suggest there to be an intragonadal $14 ; 14$ translocation; an alternative explanation is, as in Pescia et al ${ }^{45}$ unequal sister chromatid exchange producing a duplication cell line and a concomitant deletion cell line, in this instance occurring at an embryonic mitosis no earlier than during formation of germ cell precursors. From the prebanding era, Giraud et $a l^{47}$ describe a probable $45, \operatorname{dup}(13) / 46, \operatorname{rob}(13 ; 13)$; again a postzygotic sequence can be invoked with, speculatively, $45,-13 / 46, \operatorname{rob}(13: 13)$ arising at the first mitosis, and then the -13 line "self-correcting" by unequal sister chromatid exchange to produce a nearly balanced dup(13), the tiny reciprocal product being lost. On the other hand, prezygotic mechanisms appear to have been operative in the case of Blouin et al ${ }^{48}$ a patient with Down's syndrome and the karyotype $46, \mathrm{XY} / 46, \mathrm{XY}$, dir $\operatorname{dup}(21)(\mathrm{q} 11.205 \rightarrow \mathrm{q} 22.300)$. Molecular analysis indicated the abnormal chromosome to comprise segments of both maternal 21 homologues, from which the authors deduced a crossing over in meiosis I and unequal sister chromatid exchange in meiosis II. An alternative explanation is that meiosis I recombination was followed by meiosis II non-disjunction, the duplication then arising, as in Pescia et $a l{ }^{45}$ in the one cell zygote, with the tiny reciprocal product being lost. But the origin of the minor $46, \mathrm{~N}$ line (10\% in lymphocytes) remains a puzzle. The authors' suggestion of a "back mutation" is singular. Equally remarkable and more ingenious is the concept of meiotic half-chromatid duplication proposed by Cantu et $a l^{4950}$ in another case in which the normal cell line was minor $(18 \%)$, a child with $46, \mathrm{~N} / 46, \operatorname{dir} \operatorname{dup}(7)(\mathrm{p} 13 \rightarrow \mathrm{p} 22)$.

The foregoing leads us to suggest that mitotic sister chromatid exchange may be a major, but not the only means of formation of the direct duplication.

The event causing the deletion characterising Smith-Magenis syndrome (SMS) may also be susceptible to a mitotic occurrence. As well as our case 8 , Patel et $a l^{51}$ have described a patient who had some features of SMS and a $46, \mathrm{~N} / 46, \operatorname{del}(17)(\mathrm{p} 11.2)$ karyotype. They also reported a mother mosaic for $\operatorname{del}(17)(\mathrm{p} 11.2)$, discovered only because she had had a child with SMS. Finacune et $a l^{52}$ reported another case of a child with SMS mosaic for the deletion. However, four mosaic cases is not many, and it would be premature to be other than tentative and cautious about invoking a mitotic susceptibility for the occurrence of an interstitial deletion at $17 \mathrm{p} 11.2$.

Hall, ${ }^{53}$ in her seminal review of the subject, proposed that the recognition of mosaicism is, at the level of the individual person, only scratching the surface (to use the metaphor in a literal venepuncturing sense). Jacobs ${ }^{54}$ has calculated gametic chromosomal mutation rates as follows: $1.6 \times 10^{-4}$ for the balanced reciprocal translocation, and $2.95 \times 10^{-4}$ for unbalanced rearrangements. Let us consider these figures in the setting of somatic mutations (the zygote having been $46, \mathrm{~N}$ ), acknowledging (and see also below) that the chromosomal mutation rate per meiosis is surely several fold that per mitosis. The denominators are orders of magnitude less than the number of mitoses required to generate the $10^{14}$ cells comprising the human organism. The earliest a mutation could occur that would lead to somatic mosaicism is during the first mitotic cycle of the conceptus, and every succeeding cycle offers further possibility. It could be that, in the limit, numerous islands of chromosomal mutation are carried constitutionally, somewhere in their trillion cell soma, by every person. Most might be no more than single cell or few cell islets. Some of the single abnormal cells seen in 
amniotic fluid cell culture may perhaps be their representative.

In the case of mosaicism confined to gonadal tissue, at what stage of gametogenesis are such rearrangements likely to have happened? There are 30 (or more) mitotic cycles before the gametocyte enters meiosis. Because of the exponential nature of these cells' proliferation, only mutations arising in the first six or seven could come to comprise more than $1 \%\left(1 \times 2^{-6}\right.$ or $2 \times 2^{-7}$ ) of the gametic stock and have any significant chance of producing more than one affected offspring. Presumably, the vast majority of such mutations never make their presence felt. Hall, ${ }^{53}$ noting this $30: 1$ mitosis:meiosis ratio in the germ cell production line, points to a greater likelihood (if other things were equal) for germline mutations to have been mitotic. As Edwards has commented, "unless meiosis is a very much more hazardous experience for a chromosome than is mitosis, most mutations will be mitotic" 155 and he introduces the concept of "embryonic mutation rate" ${ }^{56}$ For the specific case of the structural chromosomal mutation, other things may not be equal: as there is more chromosomal interaction taking place normally at meiosis, this could offer enhanced opportunity for error. Nevertheless, unless the ratio is hugely in favour of meiotic mutation, it seems perfectly plausible that some of the "islands of mutation" mooted above could include intragonadal foci of chromosome rearrangement, which come to comprise the gonadal mosaic state.

An important practical point to be taken from the foregoing observations and theorising about gonadal mosaicism is this: most couples having had one child with a de novo nonmosaic structural rearrangement can be offered advice that, almost certainly $(99.5 \%$ or better is a fair figure to offer), the same thing would not happen in any future pregnancy. Even if one parent is a gonadal mosaic, we are led to assume that premeiotic mitotically arising abnormalities usually involve only a very small fraction of the germiniferous tissue. Very infrequently, it seems, does a cell line for a structural rearrangement comprise a substantial amount of the gonad. Nevertheless, as a general rule, prenatal diagnosis remains appropriate to cover this small risk. Tentatively, the risk may be greater in the direct duplication: about $1 \%$ is an educated guess. If a parent displays the rearrangement in somatic tissue (for example, the solitary translocation lymphocyte in our case 7), then of course an inference of its earlier generation can be drawn and thus of its probable wide gonadal distribution. In this case, the pregnancy risk could be "substantial".

As for couples who have had a child with a de novo mosaic structural rearrangement, in most cases the risk for recurrence will be extremely small, based upon the view that the majority of such abnormalities arise postzygotically in an initially normal conceptus. Prenatal diagnosis would be discretionary.

1 Bowen P, Fitzgerald PH, Gardner RJM, Biederman B Veale AMO. Duplication 8q syndrome due to familial chromosome ins(10;8)(q21;q212q22). Am f Med Genet 1983;14:635-46.

2 Fitzgerald PH, Mercer JM. Elimination of an abnormal cell line with lymphocytes during post-natal growth. Clin Genet 1980;17:433-6.

3 Kleczkowska A, Fryns JP, Van den Berghe H. On the variable effect of mosaic normal/balanced chromosomal rearrangements in man. $f$ Med Genet 1990;27:505-7.

4 Schinzel A. Catalogue of unbalanced chromosome aberrations in man. Berlin: de Gruyter, 1983.

5 Chilcote RR, Le Beau MM, Dampier C, et al. Association of red cell spherocytosis with deletion of the short arm of chromosome 8. Blood 1987;69:156-9.

6 Sciorra LJ, Schlenker E, Toke D, Brady-Yasbin S, DaySalvatore D, Lee ML. Low level mosaicism for balanced 7;14 translocation in the father of an abnormal $7 \mathrm{q}+$ child. Am $\mathcal{F}$ Med Genet 1992;42:296-7.

7 Farrell SA. Balanced reciprocal translocation mosaicism new cases and a literature review. Am $\mathcal{f}$ Med Genet 1991;40:345-7.

8 Friedman JM, Harrod MJE, Howard-Peebles PN. Complementary duplication and deletion of $17(p c e n \rightarrow p 11.2)$ a family with a supernumerary chromosome comprised of an interstitially deleted segment. $\mathrm{Am} \mathbf{f} \mathrm{Med}$ Genet 1992;44:37-40.

9 Hajianpour A, Murer-Orlando M, Docherty Z. Germline mosaicism for chromosome 5 "cri-du-chat" deletion? Am f Hum Genet (Suppl) 1991;49:217A

10 Brandriff B, Gordon LA, Crawford BB, et al. Sperm chromosome analysis to assess potential germ cell mosaichromosome Clin Genet 1988;34:85-9.

11 Yang SJ, Rosenberg HS. 21/22 translocation Down's syndrome: a family with unusual segregating patterns. $A m \mathcal{F}$ Hum Genet 1969;21:248-51

12 Pflueger S, Golden J, Troiano R, Gasparini R, Marini T. Fission of familial $(13 ; 22)$ Robertsonian translocation Fission of familial (13;22) Robertsonian translocation
resulting in fetal mosaicism. Am 7 Hum Genet (Suppl) resulting in fe

13 Kruger G, Gotz J, Dunker H, Pelz L. Isochromosome (18q) in siblings. Clin Genet 1987;32:249-53.

14 Croci G, Franchi F. Parental mosaicism in de novo translocation (21q21q) Down's syndrome. $f$ Med Genet 1991;28:502.

15 Bartsch O, Schwinger E, Konig U, Petersen MB, Palau F, Prieto F. FISH and DNA studies in a family with two siblings with dup(21q) Down syndrome. Proceedings of the European Society of Human Genetics, Elsinore, 1992:43A.

16 D'Alessandro E, Santiemma V, Lo Re ML, Ligas C, Del Porto G. 6p23 deletion mosaicism in a woman with recurrent abortions and idiopathic hypoprolactinemia. Am ₹ Med Genet 1992;44:220-2.

17 Sciorra LJ, Lee ML, Cuccurullo G. Translocation mosaicism in a woman having multiple miscarriages. $\mathrm{Am} \mathcal{f} \mathrm{Med}$ Genet 1985;22:615-17.

18 Pagon RA, Hall JG, Davenport SLH, Aase J, Norwood TH, Hoehn HW. Abnormal skin fibroblast cytogenetics in four dysmorphic patients with normal lymphocyte in four dysmorphic patients with normal lympl
chromosomes. Am $\mathcal{f}$ Hum Genet 1979;31:54-61.

19 Nielsen J, Homma A, Rasmussen K, Ried E, Sorensen K, Saldana-Garcia $P$. Deletion $14 q$ and pericentric inversion Saldana-Garcia P. Deletion 14q
14. $₹$ Med Genet 1978;15:236-8.

20 Saura R, Longy M, Serville F, Chokairi O, Froute MF. Abnormal phenotype in a child with a "balanced" translocation $8 / 12$ in mosaic state. Am $f$ Med Genet 1987;28:1021-3.

21 Wilson MJ, Lin MS. Prenatal diagnosis of mosaicism for del(18)(q12.2q21.1) and a normal cell line. $\mathcal{F}$ Med Genet

22 Gordon K, Siu VM, Sergovich F, Jung J. 18q- mosaicism associated with Rett syndrome phenotype. $\mathrm{Am} \mathcal{J} \mathrm{Med}$ Genet 1993;46:142-4

23 Robinow M, Haney N, Chen $\mathrm{H}$, et al. Secondary trisomy or mosaic "tetrasomy" 8p. Am f Med Genet 1989;32:320-4. 4 Stanley WS, Powell CM, Devine GC, et al. Mosaic 5p tetrasomy. Am J Med Genet 1993;45:774-6.

25 Hunter AGW, Clifford B, Cox DM. The characteristic physiognomy and tissue specific karyotype distribution in the Pallister-Killian syndrome. Clin Genet 1985;28:47-53.

26 Priest JH, Rust JM, Fernhoff PM. Tissue specificity and stability of mosaicism in Pallister-Killian $+\mathrm{i}(12 \mathrm{p})$ syndrome: relevance for prenatal diagnosis. Am $f$ Med Genet 1992;42:820-4.

27 Sutherland GR, Carter RF. 46,XX/46,XX,r(2)(p25q37) mosaicism: clinical and cytogenetic studies. Ann Genet (Paris) 1978;21:164-7.

28 Nyberg RH, Haapala AK, Simola KOJ. A case of human chimerism detected by unbalanced chromosomal translochition. Clin Genet 1992;42:257-9.

29 Aughton DJ, AISaadi AA, Canady AI, Lucas BM. Balanced reciprocal translocation mosaicism associated with an reciprocal translocation mosaicism associated with an

30 Macgregor DJ, Imrie S, Tolmie JL. Outcome of de novo bacgregor DJ, Imrie S, Tolmie JL. Outcome of de novo
balanced translocations ascertained prenatally. $f$ Med balanced translocatio

31 Blancato J, Hunt M, George J, Katz J, Meck J. Varying levels of mosaicism in tissues of a prenatally diagnosed case of tetrasomy 12p. Am f Hum Genet (Suppl) 1991;49:257.

32 Genovese MJ, Krawczun MS, Jenkins EC, et al. Blood/skin mosaicism for chromosomal aberration. Am $\mathcal{f}$ Hum Genet (Suppl) 1991;49:283

33 Golden WL, Kirson L, Doty L, Wilson WG. Prenatal detection of a true mosaic for a balanced reciprocal translocation. Am $\mathcal{F}$ Hum Genet (Suppl) 1991;49:216A. 
34 Papenhausen PR, Mueller OT, Kousseff BG, Tedesco TA. Partial trisomy 21 (q22.1 $\rightarrow$ qter due to a duplication on the Partial trisomy 21(q22.1 $\rightarrow$ qter due to a duplication on the
short arm inherited from an asymptomatic mosaic short arm inherited from an asymptomatic

35 Powell CM, Ellingham TJ, Rosenbaum KM, Stanley WS. Unbalanced 15;18 translocation in a Prader-Willi patient mosaic for a normal cell line. Am $\mathfrak{f}$ Hum Genet (Suppl) mosaic for a n

36 Tsien F, Blackman V, Varela M, Shapira E. Mosaicism $46, X X, 47, X X,+\operatorname{mar}$ and $47, X X,+\operatorname{der}(9) t(9 ; 9)(\mathrm{p} 13 ; \mathrm{q} 34)$ expressed to different extents in different tissues in a phenotypically normal girl. Am f Hum Genet (Suppl) 1991;49:277A.

37 Ritter CL, Steele MW, Wenger SL, Cohen BA. Chromosome mosaicism in hypomelanosis of Ito. Am $\mathcal{F}$ Med Genet 1990;35:14-17.

38 Sybert VP, Pagon RA, Donlan M, Bradley CM. Pigmentary abnormalities and mosaicism for chromosomal aberration: association with clinical features similar to hypomelanosis of Ito. F Pediatr 1990;116:581-6.

39 Borgaonkar DS. Chromosomal variation in man. A catalog of chromosomal variants and anomalies, 5th ed. New York: Liss, 1989:xxiii.

40 Van Dyke DL. Isochromosomes and interstitial tandem direct and inverted duplications. In: Daniel $\mathrm{A}$, ed. The cytogenetics of mammalian autosomal rearrangements. Progress and topics in cytogenetics, vol 8. New York: Liss, 1988:635-65.

41 Serotkin A, Stamberg J, Waber L. Duplication 17q mosaicism: an infant with features of Ellis-van Creveld syndrome. $\mathcal{F}$ Med Genet 1988;25:258-60.

42 Dixon JW, Costa T, Teshima IE. Mosaicism for duplication $12 \mathrm{q}(12 \mathrm{q} 13 \rightarrow \mathrm{q} 24.2)$ in a dysmorphic male infant. $f$ tion $12 \mathrm{q}(12 \mathrm{q} 13 \rightarrow \mathrm{q} 24.2)$

43 Harrod MJE, Byrne JB, Dev VG, Francke U. Duplication $12 \mathrm{q}$ mosaicism in two unrelated patients with a similar 12q mosaicism in two unrelated patients

44 Jewell AF, Simpson GF, Pasztor L, Keene CL, Sullivan BA, Schwartz S. Prenatal diagnosis of two cases of de novo dup(12p), identified by fluorescence in situ hybridization (FISH). Am f Hum Genet (Suppl) 1992;51:81A.
45 Pescia G, Tonella A, Jotterand-Bellomo M. Monosomie/ trisomie 4q12-q13 en mosaique chez un enfant arrieree et dysmorphique. Ann Genet (Paris) 1982;25:110-12.

46 dysmorphique. Ann Genet Paris R, Sanger WG. Partial deletion of $14 q$ and partial duplication of $14 q$ in sibs: testicular mosaicism for $\mathrm{t}(14 \mathrm{q} ; 14 \mathrm{q})$ as a common mechanism. Am f Med Genet 1989;34:528-34.

47 Giraud F, Hartung M, Brusquet Y, Stahl A, Bernard R. Mosaique chromosomique complexe: trisomie $\mathrm{D} /$ disomie partielle pour un grand telocentrique. Pediatrie 1967;22:711-18

48 Blouin JL, Aurias A, Creau-Goldberg N, et al. Cytogenetic and molecular analysis of a de novo tandem duplication of chromosome 21. Hum Genet 1991;88:167-74.

49 Cantu JM, Rivas F, Ruiz C, Barajas LO, Moller M, Rivera $\mathrm{H}$. Trisomy $7 \mathrm{p}$ due to mosaic normal/dir dup $(7)($ p13 $\rightarrow$ p22). Syndrome delineation, critical segment assignment, and a comment on duplications. Ann Genet (Paris) 1985;28:254-7.

50 Cantu JM, Ruiz C. On a prezygotic origin of normal/ balanced translocation mosaicism. Ann Genet (Paris) 1986;29:221-2.

51 Patel PI, Heiu Z, Zori RT, Zackowski JL, Greenberg F, Lupski JR. Mosaicism for del(17)(p11.2): clinical, cytogenetic and molecular analysis of two cases. Am $\mathcal{J}$ Hum Genet (Suppl) 1992;51:12A.

52 Finucane BM, Kurtz MB, Babu VR, Scott CI. Mosaicism for deletion $17 \mathrm{p} 11.2$ in a boy with the Smith-Magenis syndrome. Am $\mathcal{F}$ Med Genet 1993;45:447-9.

53 Hall JG. Review and hypotheses. Somatic mosaicism: observations related to clinical genetics. Am $\mathcal{f}$ Hum Genet 1988;43:355-63.

54 Jacobs PA. Mutation rates of structural chromosome rearrangements in man. Am $\mathcal{f}$ Hum Genet 1981;33:44-54.

5 Edwards JH. Heterogeneity. Ann NY Acad Sci 1991;615:344-53.

56 Edwards JH. The population genetics of Duchenne: natural and artificial selection in Duchenne muscular dystrophy. f Med Genet 1986;23:521-30.

\section{Addendum}

The mother's parents' chromosomes in case 10 have since been analysed and are normal. The inv $\operatorname{dup}(15)$ is further identified on FISH with D15S11 and D15Z2 (Dr A Smith) as iso dic(15)(q11). 